\title{
Anticancer drugs-related QTc prolongation, torsade de pointes and sudden death: current evidence and future research perspectives
}

\author{
Jialin Duan' ${ }^{1}$, Jingwen Tao${ }^{1}$, Maocai Zhai ${ }^{1}$, Chengpeng Li ${ }^{2}$, Ning Zhou ${ }^{1}$, Jiagao Lv ${ }^{1}$, \\ Lin Wang ${ }^{1}$, Li Lin ${ }^{1}$ and Rong $\mathrm{Bai}^{3,4}$ \\ ${ }^{1}$ Division of Cardiology, Department of Internal Medicine, Tongji Hospital, Tongji Medical College, Huazhong University of \\ Science and Technology, Wuhan, P.R. China \\ ${ }^{2}$ Department of Cardiology, Wuhan Hospital of Integrated Traditional Chinese and Western Medicine, Wuhan, P.R. China \\ ${ }^{3}$ Department of Cardiology, An Zhen Hospital, Capital Medical University, Beijing, P.R. China \\ ${ }^{4}$ Texas Cardiac Arrhythmia Institute at St. David's Medical Center, Austin, TX, USA \\ Correspondence to: Li Lin, email: linlee271227@163.com \\ Rong Bai, email: bairong74@gmail.com \\ Keywords: anticancer therapy; QT interval prolongation; torsade de pointes; molecularly targeted drugs \\ Received: June 01, $2017 \quad$ Accepted: March 13, $2018 \quad$ Published: May 22, 2018 \\ Copyright: Duan et al. This is an open-access article distributed under the terms of the Creative Commons Attribution License 3.0 \\ (CC BY 3.0), which permits unrestricted use, distribution, and reproduction in any medium, provided the original author and source \\ are credited.
}

\section{ABSTRACT}

Anticancer drugs may have proarrhythmic effects including drug-induced QT interval prolongation, which is of particular importance because it can lead to a fatal polymorphic ventricular tachycardia termed torsade de pointes (TdP). QT interval prolongation and TdP are rare life-threatening untoward effects of anticancer therapy, particularly with arsenic trioxides and anthracyclines, and even some novel molecular targeted drugs touted as 'tumor specific'. Several factors that affect myocardial repolarization can further increase the risk of TdP. This article reviews the mechanism of QT interval prolongation, risk factors for TdP and the QT toxicity of anticancer drugs as well as its management. Specific attention should be paid to high-risk populations such as patients with underlying heart diseases, electrolyte imbalance and bradycardia. To minimize the occurrence of $Q T$ interval prolongation and TdP, it is advisable to conduct a careful risk factor assessment before antitumor therapy. To this end, several new biomarkers have been introduced to predict TdP triggering and recent studies have pointed out the potential clinical relevance of genetic testing.

\section{INTRODUCTION}

Cancer treatment has greatly benefited from recent developments in drug therapy. However, anticancer drugs despite their increased target specificity are not without toxicities, and among cardiac ones, prolongation of the QT interval is particularly concerning [1]. Many drugs affect heart repolarization and prolong the QT interval, thereby increasing the risk for torsades de pointes (TdP), a lethal ventricular arrhythmia, and sudden cardiac death. QT- interval prolongation and TdP not uncommonly underlie drug withdrawal from the market [2].

The term torsades de pointes (Figure 1) was first introduced by Dessertenne in 1966 as "a polymorphic ventricular tachycardia where QRS complexes twist around an isoelectric line" on the surface electrocardiogram (ECG) $[3,4]$. Although polymorphic ventricular tachycardia with normal QT interval is also called TdP, its treatment is very different and most scholars stress that TdP only refers to polymorphic ventricular tachycardia with prolonged QT interval [5]. 


\section{QT INTERVAL MEASUREMENT}

The QT interval as measured on an ECG is measured from the beginning of the QRS complex to the end of the $\mathrm{T}$ wave, reflecting the depolarization and repolarization of both left and right ventricles. Usually, the QT interval is measured in lead II [12] and should be determined as a mean value derived from at least 3-5 cardiac cycles [6]. The QRS duration also influences the QT interval when perturbed by pre-excitation, bundle branch block, or pacemaker implantation. In these situations, the JT interval may offer more information [7, 8, 9]. Figure 2 QT and JT interval measurement with ECG [9], although standards for the JT interval are unclear at this time. The QT interval is closely related to heart rates, so a correction of the QT interval for heart rates is necessary. Bazett's formula $\left(\mathrm{QT}_{\mathrm{C}}=\mathrm{QT} / \mathrm{RR}^{1 / 2}\right)$ and the Fridericia formula $\left(\mathrm{QT}_{\mathrm{C}}=\mathrm{QT} / \mathrm{RR}^{1 / 3}\right)$ are widely used to correct the QT interval. Bazett's formula is considered to be the standard for this type of measurement although it may exaggerate the QT interval at fast heart rates $[10,11]$. The Fridericia formula has similar problems but is more accurate with tachycardia $[10,11]$, and for patients with atrial fibrillation, the Fridericia formula is preferred [13]. $\mathrm{A} \mathrm{QT}_{\mathrm{C}}<450 \mathrm{~ms}$ in women and a $\mathrm{QT}_{\mathrm{C}}<430 \mathrm{~ms}$ in men is considered abnormal with a stable sinus rate. $\mathrm{QT}_{\mathrm{C}}$ values from 450 to $470 \mathrm{~ms}$ in women and 430 to $450 \mathrm{~ms}$ in men are considered borderline [6]. Values of $\mathrm{QT}_{\mathrm{C}}>500 \mathrm{~ms}$ are considered strikingly abnormal because deadly arrhythmic events can occur at this value.

\section{MECHANISM OF DRUG-INDUCED QT PROLONGATION}

The QT interval as measured by ECG represents the total duration of ventricular depolarization and repolarization. Generally, the process of ventricular depolarization is much shorter than that of repolarization. Hence, factors that prolong ventricular action potential duration, especially repolarization, prolong the QT interval. An increase in the inward current and a decrease in an outward current will delay action potential duration. Among the ion currents of the action potential, two delayed rectifier potassium current subtypes, $\mathrm{I}_{\mathrm{Kr}}$ (rapid) and $\mathrm{I}_{\mathrm{Ks}}$ (slow) are important to ventricular repolarization [14]. Blockade of $\mathrm{I}_{\mathrm{Kr}}$ which is encoded by the human ether-a-go-go-related gene (HERG) of chromosome 7 is the most common target of drug-induced QT prolongation [15]. The HERG channel (the $\mathrm{KCNH} 2$ potassium voltage-gated channel) is responsible for most QT-associated drug toxicity. However, HERG channel blockade is not necessarily related to QT prolongation. For example, raloxifene inhibits cardiac delayed rectifier potassium currents but does not lead to QT prolongation [16], underscoring uncertainties regarding the mechanism of drug-induced QT prolongation.

Figure 3 Arsenic trioxide blocks both $\mathrm{I}_{\mathrm{Kr}}$ and $\mathrm{I}_{\mathrm{Ks}}$ at clinically relevant concentrations and activates the $\mathrm{I}_{\mathrm{K} \text {-ATP }}$ which maintains normal repolarization [17]. Oxaliplatin might prolong QT interval by increasing $\mathrm{Na}^{+}$influx due to prolonged opening of $\mathrm{Na}^{+}$channels [18]. However, the mechanisms underlying QT toxicity of many molecularly targeted cancer drugs need to be defined.

\section{RISK FACTORS AND PREMONITORY SIGNS OF TDP IN ECG}

There are many risk factors (Table 1) for druginduced long QT syndrome (diLQTS), including those that damage repolarization reserve, a term introduced by Roden [19] to reflect that normal cardiac repolarization depends on multiple ion currents which provide some

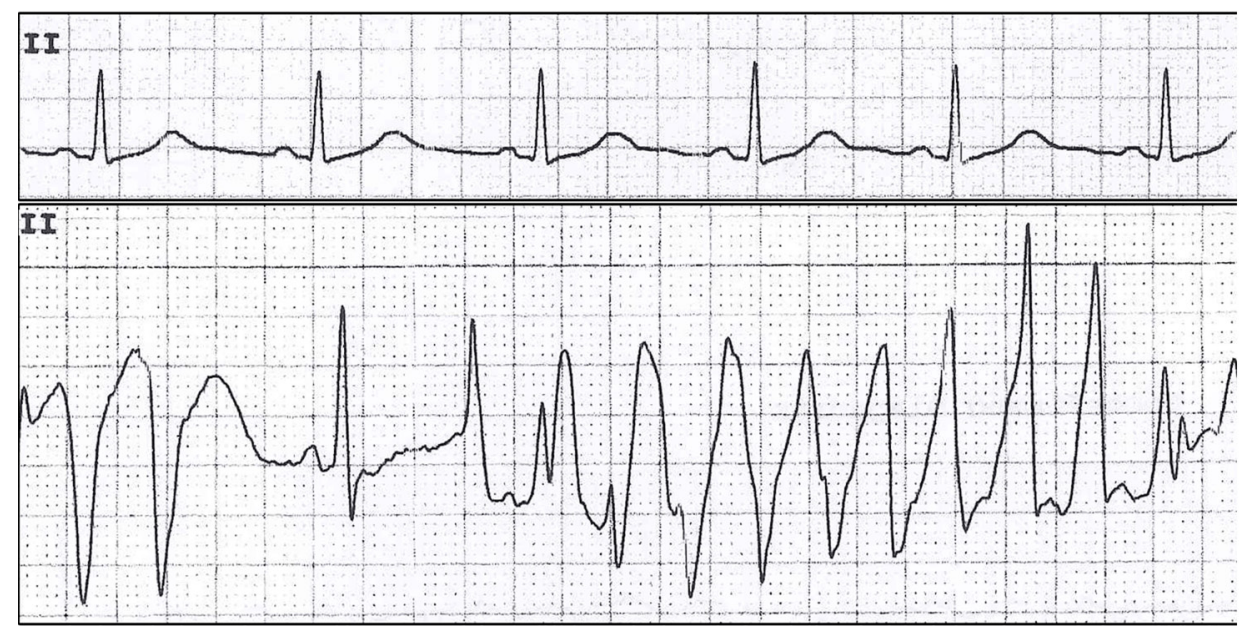

Figure 1: TdP in a patient with distant metastatic (M1) gastric adenocarcinoma undergoing oxaliplatin treatment. 
redundancy or "reserve," which protects against excessive QT prolongation by xenobiotics [19].

The ECG often features predictors of TdP. First, significant QT and QTc interval prolongation is essential for $\mathrm{TdP}$ - each 10-ms increase in QTc contributes a $\sim 5$ $7 \%$ exponential increase in TdP risk [20]. Almost all case reports of TdP caused by antineoplastic drugs occurred with a QTc>500 ms. Secondly, "short-long-short" patterns of R-R intervals (Figure 4) are often observed prior to $\mathrm{TdP}$ and this pattern consists of short-coupled premature ventricular complex (PVC) followed by a compensatory pause and then a second PVC that typically falls close to the peak of the T wave [5]. The first PVC is thought to increase the heterogeneity of repolarization of the next sinus beat and provoke TdP. Thirdly, T-wave alternans (TWA; Figure 5) which is a rare but dangerous ECG manifestation of TdP, manifests as a regular alternation of T-wave morphology with each beat [21] reflecting an instability of ventricular repolarization that predisposes to TdP.

\section{CLASSIC ANTINEOPLASTIC DRUGS}

\section{Arsenic trioxide}

Arsenic trioxide, which is widely used in patients with acute promyelocytic leukemia (APL), might cause prolongation of the $\mathrm{QT}$ interval and $\mathrm{TdP}$ at therapeutic doses [22]. Previous studies suggest that-compared with baseline - the $\mathrm{QT}_{\mathrm{C}}$ interval was prolonged by 30-60 ms in $36.6 \%$ of treatment courses, and by more than $60 \mathrm{~ms}$ in $35.4 \%$ of patients [23]. The precise mechanism of arsenic trioxide-induced QT prolongation is complicated and the research results differ among species [24]. Furthermore, a recent study suggests that arsenic trioxide-induced cardiac fibrosis may involve in diLQTS [25]. In reported cases, arsenic trioxide-induced TdP frequently occurred several (usually more than 20) days after the start of therapy and other risk factors were present (Table 1) [26, 27], emphasizing the need for monitoring ECG and serum electrolyte data throughout therapy. Mild prolongation of the QT interval (440-500 ms) is common during treatment and does not limit the use of arsenic trioxide. Alpha lipoic acid has been reported to be protective against arsenic trioxide-induced QT interval prolongation in anesthetized guinea pigs [28], suggesting a potential approach for preventing arsenic trioxide-induced LQTS.

\section{Anthracyclines}

Anthracyclines are effective for treating various tumors, including solid ones, and hematologic malignancies. However, the severe cardiotoxicity of anthracyclines has limited their use. QT interval prolongation and TdP are important signs of cardiotoxicity and there are several mechanisms of anthracycline-

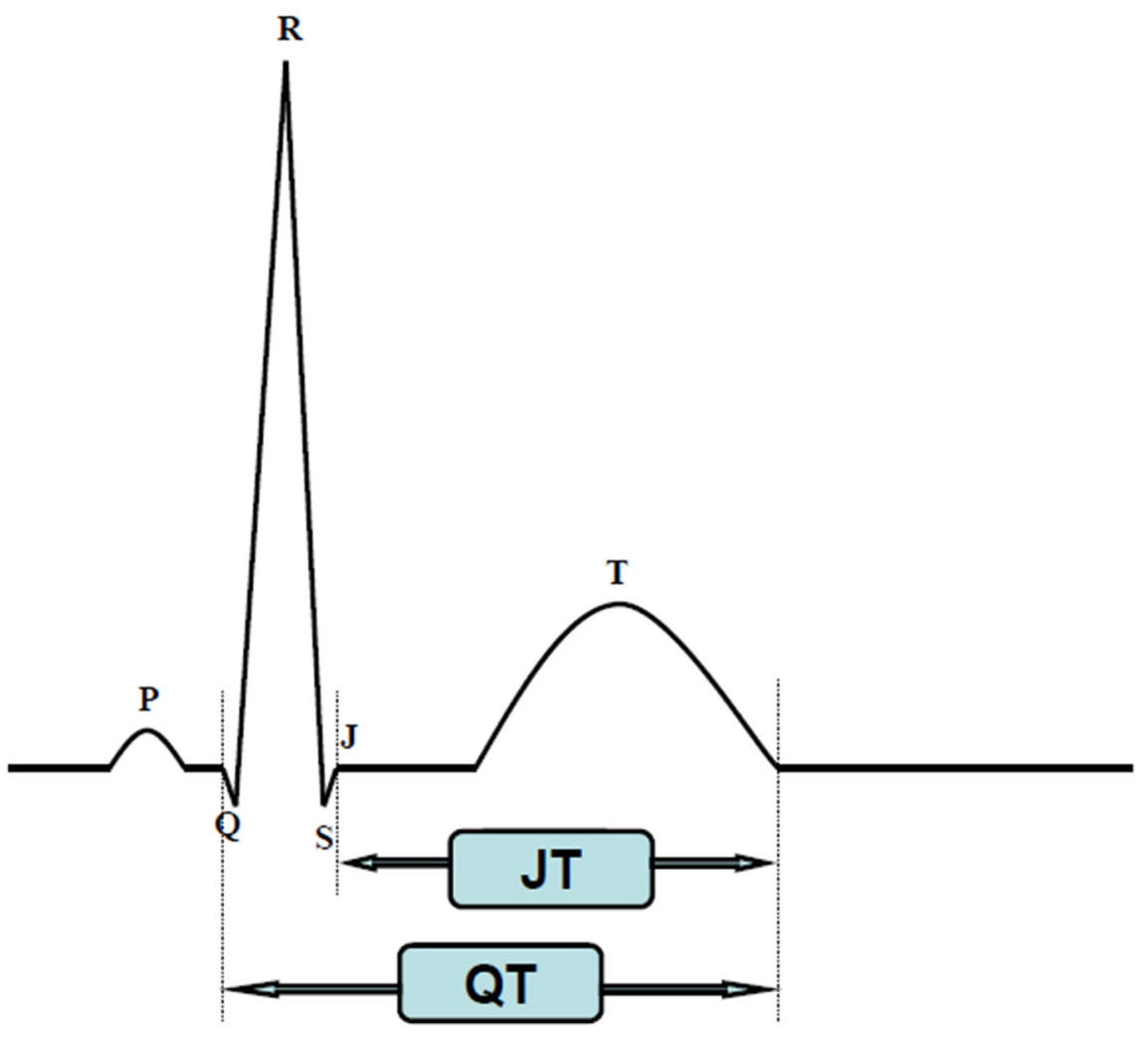

Figure 2: QT and JT interval measurement with ECG. 
induced LQTS including effects on cardiomyocytes and ion currents. A plausible explanation for anthracyclineinduced cardiomyocyte injury is the generation of reactive oxygen species (ROS) leading to oxidative stress [29, 30]. Ion channel effects also contribute to anthracyclineinduced QT prolongation. Anthracycline treatment can increase sensitivity to the pro-arrhythmic potential of $\mathrm{I}_{\mathrm{Kr}}{ }^{-}$ blocking drugs and reduce redepolarization reserve [31] increasing patient susceptibility to drugs that promote TdP. Several cases of anthracycline-induced LQTS have been reported [32], mostly in female patients, one of whom died of TdP and ventricular fibrillation [33]. Most patients in the study were within the recommended safe dose range and the risk was conferred from weeks to years of anthracycline therapy. Risk factors such as hypokalemia and drug-drug interactions were common in these cases, specifically interactions between azole derivatives and arsenic trioxide. Dexrazoxane is FDA approved for prevention of anthracycline cardiotoxicity in women with breast cancer.

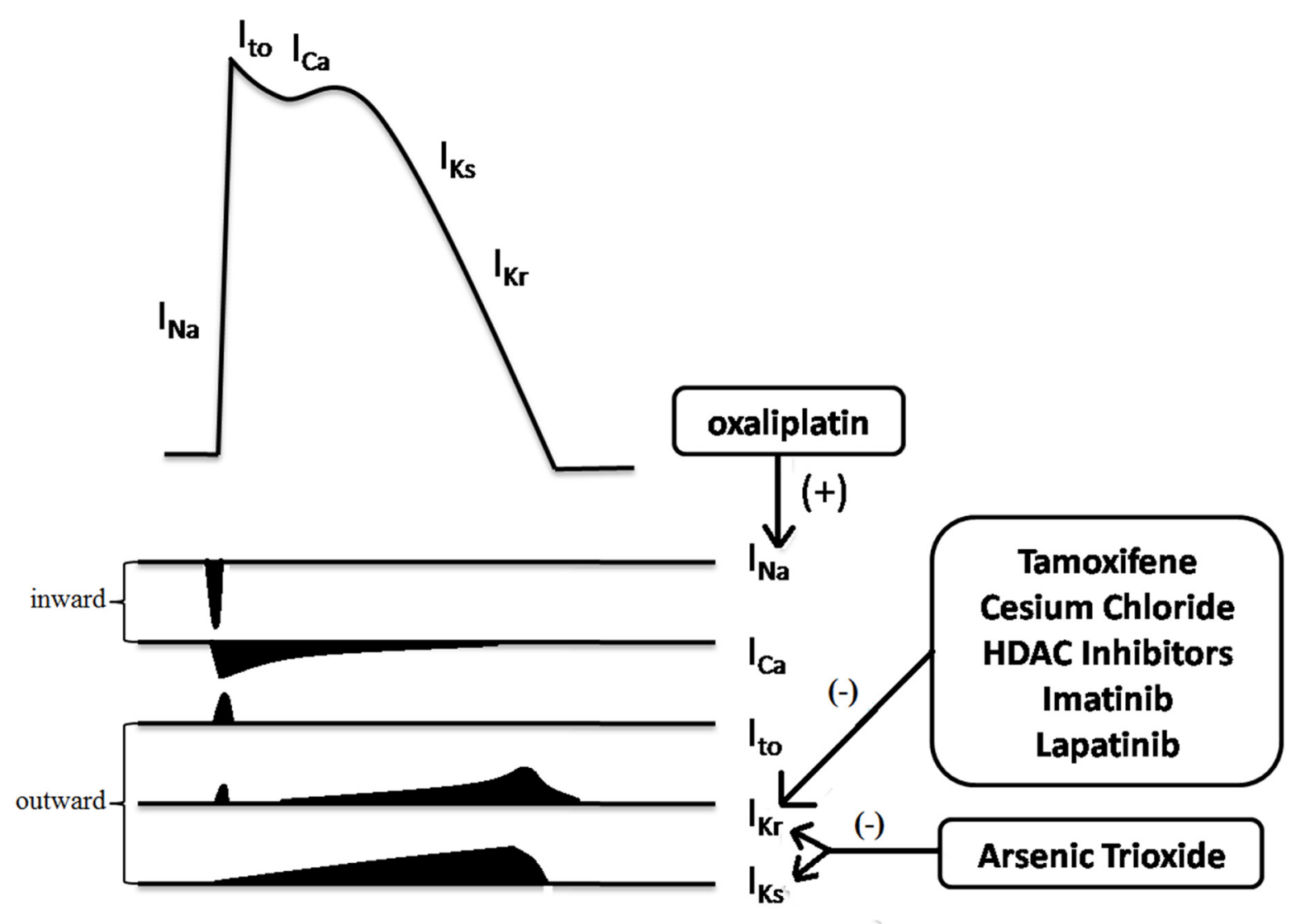

Figure 3: Multiple ion currents involved in the myocardial action potential. Among them, $\mathrm{I}_{\mathrm{Kr}}(\mathrm{HERG})$ is the most common target for anticancer drugs induced QT prolongation. Arsenic trioxide and oxaliplatin prolong the QT interval in unique ways. $(+)$ represented for enhancing and (-) for inhibiting. $I_{\text {to }}$, transient outward potassium current.

\section{Other classic drugs}

Tamoxifen and its derivatives (4-hydroxytamoxifen) have been associated with QT interval alterations likely due to HERG potassium channel blockade [33]. 4-hydroxytamoxifen has been reported to inhibit $\mathrm{K}^{+}$ currents in mouse ventricular myocytes [34], and effects on calcium channels also contribute to QT-interval prolongation. A recent study suggests that high-dose tamoxifen decreases contraction amplitude, slows relaxation, and decreases the $\mathrm{Ca}^{2+}$ transient amplitude, which may explain tamoxifen-induced LQTS [35].

Platinum compounds have been associated with QT interval prolongation and TdP, especially oxaliplatin [36, 38, 39]. Oxaliplatin can increase $\mathrm{Na}^{+}$influx by prolonging $\mathrm{Na}^{+}$channel opening, thereby affecting cardiac repolarization [18]. Acetyl-L-carnitine, DL- $\alpha$-lipoic acid and silymarin can ameliorate cardiotoxicity associated with cisplatin in rats [37], but further studies are needed before human use is considered.

Cesium chloride, an alternative or second-line treatment for several cancers, also has been reported 
Table 1: Common clinical risk factors for drug-induced QT prolongation and TdP [19]

\section{Female}

Conditions predisposing to heightened QT prolongation and risk of arrhythmia

Heart disease

Congestive heart failure

Left-ventricular hypertrophy

Hours following conversion of atrial fibrillation to sinus rhythm

Congenital long-QT syndrome (may be clinically unrecognized)

Bradycardia and conduction disease

Increased drug bioavailability

Altered function of specific cytochrome P450 (CYP450) isoforms (for liver metabolized drugs) Genetic variants

Concomitant inhibitory drugs

Liver disease

Altered renal or liver function (for renally or hepatically excreted drugs)

Electrolyte imbalance

Hypokalaemia

Hypomagnesaemia

Hypocalcaemia (possible)

Administration of other drugs which might cause QT prolongation

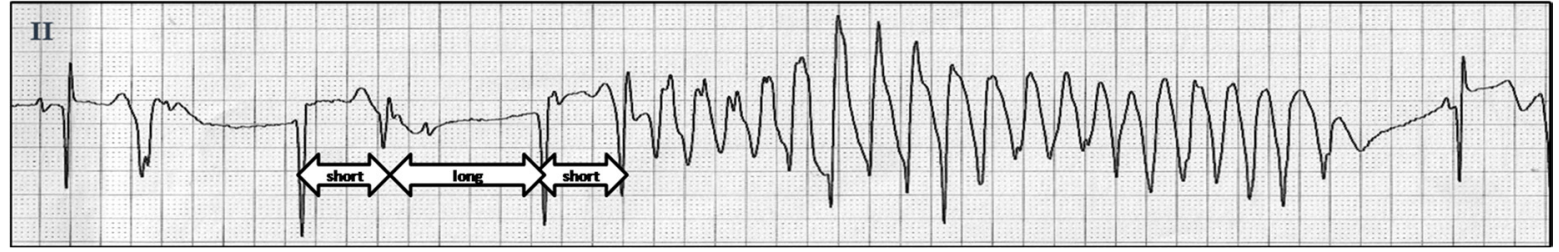

Figure 4: "Short-long-short" pattern prior to triggering a TdP.

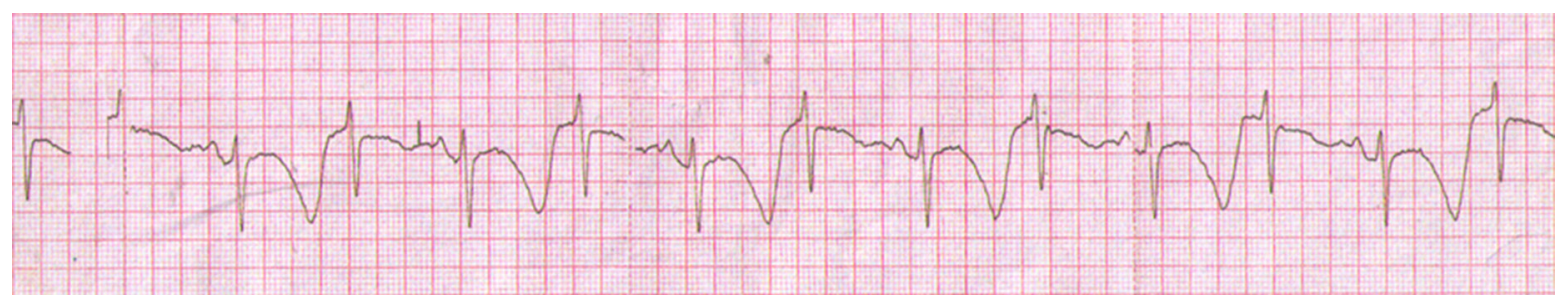

Figure 5: TWA in a patient with congenital long QT syndrome. Minutes later, the patient developed TdP. 
to induce LQTS [41, 42, 43, 44]. TdP occurred several weeks to one year after cesium therapy in the presence of multiple risk factors (female gender, hypokalemia, and bradycardia). Cesium chloride blocks HERG potassium channels, prolonging the QT interval and inducing TdP [45]. Prussian blue has been reported to treat cesium chloride-induced LQTS [41].

5-fluorouracil, Cesium chloride, cyclophosphamide, paclitaxel and docetaxel are often associated with QTinterval prolongation [40], but this complication is infrequent and often due to high doses of the drugs or to drug-drug interactions.

\section{NOVEL ANTINEOPLASTIC DRUGS}

\section{Trastuzumab}

Trastuzumab, a monoclonal antibody against the Her2 signaling pathway, is widely used in Her2 metastatic breast carcinoma and acute trastuzumab infusion has been shown to have no effect on cardiac repolarization and the QT interval [47]. However, a recent study suggests that long-term (12 weeks) treatment with trastuzumab significantly prolonged QT intervals and increased QTd (QT dispersion) in patients with breast cancer [46]. Thus, chronic cardiomyocyte toxicity of trastruzumab may contribute to QT alterations. ACE inhibitors and betablockers can prevent trastuzumab-induced cardiotoxicity and recent clinic trials suggest that combined therapy with ACE inhibitors/angiotensin receptor blockers and betablockers may prevent trastuzumab-related cardiotoxicity [48].

\section{HDAC inhibitors}

QT prolongation and TdP has also been observed in patients taking histone deacetylase with prolongation of the QT interval and sudden cardiac death in clinical trials. In a phase II study with 15 patients with metastatic neuroendocrine tumors, after an infusion of depsipeptide, one patient died suddenly and this was attributed to possible fatal ventricular arrhythmia. Two other patients had asymptomatic nonsustained ventricular tachycardia, and prolonged QT was noted in three patients [49]. Vorinostat, a HDAC inhibitor used to treat cutaneous T-cell lymphoma (CTCL), has been reported to induce TdP in a 49-year-old African American man [50]. Other HDAC inhibitors, such as romidepsin and LAQ824 have also been associated with QT-interval prolongation, but no fatal ventricular arrhythmia has been reported [51, 52]. HDAC inhibitor-induced QT interval prolongation and TdP is thought to occur via HERG channel blockade, but this is uncertain. The development of new HDAC inhibitors that are highly efficacious but with weak affinity for hERG may offer a way to prevent such adverse reactions.

\section{Tyrosine kinase inhibitors}

The development of tyrosine kinase inhibitors (TKIs) is one of the most important advances in anticancer therapy these years. They have been widely used in solid tumors and hematologic malignancies. However, their use has been associated with underlying cardiac toxicities including hypertension, left ventricular dysfunction and QT prolongation [53]. Many TKIs, including crizotinib, ponatinib, nilotinib, cediranib, vandetanib, lapatinib, sunitinib, Bosutinib, Dasatinib, Lenvatinib, Osimertinib, Pazopanib, Ceritinib, imatinib, are associated with QT prolongation [54-61, 84-90]. Among them, Crizotinib deserves special mentioned. Crizotinib, an anaplastic lymphoma kinase (ALK) inhibitor, is FDA-approved for the treatment of nonsmall cell lung carcinoma (NSCLC) [62]. However, it has been associated with QT bradycardia and prolongation. In two clinical trials, 4/306 with QTc $\geq 500 \mathrm{~ms}$ and $\Delta \mathrm{QTc} \geq 60 \mathrm{~ms}$ in $10 / 289$ were observed [63]. Besides, according to Ou's research, there was an average decrease of 26.1 beats per minute (bpm) from pretreatment heart rate (HR) among all patients on crizotinib [64]. As mentioned, QT prolongation is more dangerous with bradycardia, so carefully monitoring in patients under the treatment of crizotinib is necessary. According to the formal studies, imatinib could preferentially block the open HERG channel, contributing to QT interval prolongation [65]. Lapatinib can block the HERG channel in transfected HEK293 cells and prolong the action potential duration [66], prolonging the QT interval. These data suggest that HERG channel blockade may explain QT prolongation, but more work is required.

\section{Rituximab}

Rituximab is an anti-CD20 monoclonal antibody and effective for patients with lymphoid malignancies. However, cardiotoxicity of rituximab is likely underreported. A case report regarding rituximab-induced polymorphic ventricular tachycardia [67] suggests that a female patient with malignant lymphoma who had undergone atrioventricular nodal ablation and pacemaker implantation, developed syncope due to polymorphic ventricular tachycardia during an initial rituximab infusion. Unfortunately, the ECG was not timely, and the arrhythmia was recorded by intracardiac electrogram from pacemaker interrogation, complicating the recognition of TdP. The QT interval was prolonged according to the ECG recorded later, underscoring the possibility that TdP should not be excluded. Other cardiac adverse reactions from rituximab, including acute coronary syndromes and complete atrioventricular block were observed [68, 69, $70]$, but how these occurred is unclear. 
Table 2: Antineoplastic drugs that prolong the QT interval

\begin{tabular}{|c|c|c|c|}
\hline Drugs & Effect of $Q T$ & $T d P$ & References \\
\hline \multicolumn{4}{|l|}{ Classic drugs } \\
\hline Arsenic Trioxide & $\begin{array}{c}37 \% \text { with } 30-60 \mathrm{~ms} \uparrow, 35 \% \\
\text { with }>\text { than } 60 \mathrm{~ms} \uparrow\end{array}$ & + & {$[23,26,27]$} \\
\hline Anthracycline & $\begin{array}{c}9.56 \mathrm{~ms} \uparrow \text { in doxorubicin } \\
\text { therapy }\end{array}$ & + & {$[32]$} \\
\hline Tamoxifen & Dose related & possible & [34] \\
\hline Platinum compounds & $\begin{array}{c}6.25 \% \text { in cisplatin treatment, } \\
\text { no data for oxaliplatin } \\
\text { treatment }\end{array}$ & $\stackrel{+}{+}$ & {$[36,38,39]$} \\
\hline 5-fluorouracil (5-FU) & $\begin{array}{l}\text { Significant increases in } \\
\text { QTmax and QTd were } \\
\text { observed as early as } 24 \mathrm{~h} \\
\text { after 5-FU treatment }\end{array}$ & - & {$[40]$} \\
\hline Cesium chloride & $\begin{array}{l}\text { QT prolongation usually } \\
\text { occurs with total cesium } \\
\text { intakes of } 6 \mathrm{~g} / \text { day }\end{array}$ & + & {$[41-44]$} \\
\hline \multicolumn{4}{|c|}{ Molecularly-targeted drugs } \\
\hline Trastuzumab & $\begin{array}{l}\text { Prolongs QT interval with } \\
\text { long-term treatment (12 } \\
\text { weeks) }\end{array}$ & - & {$[46]$} \\
\hline$H D A C$ inhibitors & $\begin{array}{l}36 \% \text { with vorinostat } \\
\text { treatment }\end{array}$ & $\begin{array}{c}+ \\
\text { (vorinostat and depsipeptide) }\end{array}$ & {$[49-52]$} \\
\hline Rituximab(possible) & 1 case report & possible & {$[67]$} \\
\hline TKIs & $\begin{array}{l}\text { Varieties of TKIs could lead } \\
\text { to QT interval prolongation. }\end{array}$ & - & {$[54-61,84-90]$} \\
\hline$C A 4 P$ & 23.3\% QTc prolongation & - & {$[71]$} \\
\hline$B R A F$ inhibitors & Vemurafenib and Dabrafenib & - & {$[74,91]$} \\
\hline Eribulin & a minor prolongation of QTc & - & {$[92]$} \\
\hline Bortezonib & $\begin{array}{l}2 \text { of } 11 \text { patients showed QT } \\
\text { interval prolongation }\end{array}$ & + & {$[93]$} \\
\hline
\end{tabular}

\section{Combretastatin A4 phosphate}

Combretastatin A4 phosphate (CA4P) is a vasculardisrupting agent that targets existing tumor blood vessels can causes tumor necrosis. Adverse reactions after intravenous infusion of CA4P have been documented in a pilot study as was elevated blood pressure (46.7\%), QTc prolongation (23.3\%), elevated temperature $(13.3 \%)$, and headache $(10 \%)$, as well as by nausea and eye infection(6.7\%) [71]. In a single-dose phase I study of patients with advanced cancer, significant increases in QTc intervals were observed at 3 or $4 \mathrm{~h}$ after CA4P infusion [72]. Two cases of CA4P-induced Takotsubo cardiomyopathy and QT interval prolongation were also reported [73] and for these two cases, elderly females who received combretastatin suffered severe decreased left ventricular systolic function and significant wall-motion abnormalities, but acute coronary syndrome was excluded suggesting that this acute myocardial injury might be associated with combretastatin.

\section{Other molecularly targeted drugs}

Vemurafenib, a BRAF inhibitor, is effective for treating patients with BRAF V600E mutation-positive inoperable and metastatic melanoma but this drug is associated with QT prolongation. In a single-arm, openlabel, expanded access study of vemurafenib among 374 patients, 2 patients were discontinued because of recurrent QT prolongation [74]. Thus, regular monitoring of ECGs 
is recommended during vemurafenib therapy [75]. Another BRAF inhibitor, Dabrafenib, has also been associated with QT prolongation [91].

Other molecular targeted drugs such as Eribulin (microtubule inhibitor), Bortezonib (proteasome inhibitor), are also associated with QT problems [76, 92, 93], but TdP has not been reported.

\section{DISCUSSION}

Antineoplastic drugs that prolong the QT interval are listed as Table 2. Other common cardiotoxicities of anticancer drugs include left ventricular dysfunction and myocardial ischemia. Anthracyclines, anti-Her2 agents and anti-VEGF treatments were commonly associated with acute or chronic heart failure during anticancer therapy [94]. Takotsubo syndrome of cardiomyopathy (ballooning of left ventricle) was observed in two men treated with bevacizumab for metastatic cancer [95]. The myocardial ischemia most often associated with 5-FU or its fluoropyrimidine prodrug capecitabine is coronary vasospasm [96]. Bevacizumab can also lead to arterial thromboembolic events, including myocardial infarction in $0.6---1.5 \%$ of patients [97].

Benefit/risk evaluations are warranted to improve safety of cancer therapy. Special attentions should be paid for patients undergoing chemotherapy with other factors that increase the risk of TdP, such as hypokaliemia, use of antibiotics that can prolong the QT (macrolides, quinolones) and use of psychotropic drugs. Because TdP is lethal, risk factors must be assessed and the risk must be managed where possible. Thus, more precise predictors for TdP are needed. New noninvasive biomarkers have been introduced to predict potential risks of drug-induced TdP. For example, T-wave morphology such as T(peak)$\mathrm{T}$ (end) intervals, notched $\mathrm{T}$ wave, and giant $\mathrm{T}-\mathrm{U}$ waves correlate with the risk of TdP. T(peak)-T(end) of $117 \mathrm{~ms}$ is also a reliable discriminator $[77,78]$. Microvolt TWA may predict risks for sudden cardiac death [79] being useful in drug-induced LQTS. Index of cardiac electrophysiological balance $(\mathrm{iCEB}=\mathrm{QT} / \mathrm{QRS}$ ) can help predict drug-induced cardiac arrhythmias including ventricular tachycardia/ ventricular fibrillation (VT/VF) and TdP and may be more useful than current biomarkers [80]. Pharmacogenomics also may offer ways for predicting drug-induced LQTS. As genetic test has become less expensive in few years, more and more researches based on large populations have been investigated and more variants have been found. Both pharmacokinetics and pharmacodynamics are associated with diLQTS [81]. Interestingly, five to nineteen percent of patients with drug-induced torsade de pointes carry mutations in genes involved in congenital long QT syndrome [82]. Besides, genes that affect the drug metabolism such as cytochrome P450 substrates have also been proved with diLQTS [83]. Thus, a genetic background may be one of several factors for drug-induced
LQTS. Also, specific drugs may have unique mechanisms of inducing TdP. Still, pharmacogenomics for predicting LQTS and TdP has the potential to be helpful in the future.

\section{Abbreviations}

TdP: torsade de pointes; SNP: single nucleotide polymorphism; HERG: human ether-a-go-go-related gene; ECG: electrocardiogram; TWA: T wave alternans; PVC: premature ventricular complex; APL: acute promyelocytic leukemia; LQTS: long QT syndrome; ROS: reactive oxygen species; Top $2 \beta$ : topoisomeraseII $\beta$; EDTA: ethylenediaminetetraacetic acid; HDAC: histone deacetylase; CTCL: T-cell lymphoma; CA4P: Combretastatin A4 phosphate; iCEB: Index of cardiac electrophysiological balance; GWAS: Genome wide association studies; SJS/TEN: Stevens-Johnson syndrome/ toxic epidermal necrolysis; diTdP: drug-induced torsade de pointes.

\section{CONFLICTS OF INTEREST}

The author states no conflict of interest.

\section{FUNDING}

L Lin is supported by the National Natural Science Foundation of China (NSFC-81372402). R Bai is supported from China by the Program for New Century Excellent Talents in University (NCET-09-0376); the National Natural Science Foundation (NSFC-81370290) and the Scientific Research Foundation for the Returned Overseas Chinese Scholars (SFR ROCS 2008-101). $\mathrm{N}$ Zhou is supported by the National Natural Science Foundation of China (NSFC-81100087).

\section{REFERENCES}

1. Bagnes C, Panchuk PN, Recondo G. Antineoplastic chemotherapy induced QTe prolongation. Curr Drug Saf. 2010; 5:93-96.

2. Roden DM. Drug-induced prolongation of the QT interval. N Engl J Med. 2004; 350:1013-22.

3. Dessertenne F. [Ventricular tachycardia with 2 variable opposing foci]. [Article in French]. Arch Mal Coeur Vaiss. 1966; 59:263-72.

4. Kallergis EM, Goudis CA, Simantirakis EN, Kochiadakis GE, Vardas PE. Mechanisms, risk factors, and management of acquired long QT syndrome: a comprehensive review. Sci World J. 2012; 2012:212178.

5. Drew BJ, Ackerman MJ, Funk M, Gibler WB, Kligfield P, Menon V, Philippides GJ, Roden DM, Zareba W, American Heart Association Acute Cardiac Care Committee of the Council on Clinical Cardiology; the Council on Cardiovascular Nursing, and the American College of 
Cardiology Foundation. Prevention of torsade de pointes in hospital settings: a scientific statement from the American Heart Association and the American College of Cardiology Foundation. Circulation. 2010; 121:1047-60.

6. Goldenberg I, Moss AJ, Zareba W. QT interval: how to measure it and what is "normal". J Cardiovasc Electrophysiol. 2006; 17:333-36.

7. Tsai SF, Houmsse M, Dakhil B, Augostini R, Hummel JD, Kalbfleisch SJ, Liu Z, Love C, Rhodes T, Tyler J, Weiss R, Hamam I, Winner M, Daoud EG. QTc compared to JTc for monitoring drug-induced repolarization changes in the setting of ventricular pacing. Heart Rhythm. 2014; 11:485-91.

8. Crow RS, Hannan PJ, Folsom AR. Prognostic significance of corrected QT and corrected JT interval for incident coronary heart disease in a general population sample stratified by presence or absence of wide QRS complex: the ARIC Study with 13 years of follow-up. Circulation. 2003; 108:1985-89.

9. Zhou SH, Wong S, Rautaharju PM, Karnik N, Calhoun HP. Should the JT rather than the QT interval be used to detect prolongation of ventricular repolarization? An assessment in normal conduction and in ventricular conduction defects. J Electrocardiol. 1992; 25:S131-36.

10. Indik JH, Pearson EC, Fried K, Woosley RL. Bazett and Fridericia QT correction formulas interfere with measurement of drug-induced changes in QT interval. Heart Rhythm. 2006; 3:1003-07.

11. Luo S, Michler K, Johnston P, Macfarlane PW. A comparison of commonly used QT correction formulae: the effect of heart rate on the QTc of normal ECGs. J Electrocardiol. 2004; 37:S81-90.

12. Rautaharju PM, Surawicz B, Gettes LS, Bailey JJ, Childers R, Deal BJ, Gorgels A, Hancock EW, Josephson M, Kligfield P, Kors JA, Macfarlane P, Mason JW, et al.; American Heart Association Electrocardiography and Arrhythmias Committee; Council on Clinical Cardiology; American College of Cardiology Foundation; Heart Rhythm Society; and Endorsed by the International Society for Computerized Electrocardiology. AHA/ACCF/HRS recommendations for the standardization and interpretation of the electrocardiogram: part IV: the ST segment, T and $\mathrm{U}$ waves, and the QT interval: a scientific statement from the American Heart Association Electrocardiography and Arrhythmias Committee, Council on Clinical Cardiology; the American College of Cardiology Foundation; and the Heart Rhythm Society. J Am Coll Cardiol. 2009; 53:982-91.

13. Musat DL, Adhaduk M, Preminger MW, Arshad A, Sichrovsky T, Steinberg JS, Mittal S. Correlation of QT interval correction methods during atrial fibrillation and sinus rhythm. Am J Cardiol. 2013; 112:1379-83.

14. McCauley M, Vallabhajosyula S, Darbar D. Proarrhythmic and Torsadogenic Effects of Potassium Channel Blockers in Patients. Card Electrophysiol Clin. 2016; 8:481-93.
15. Vandenberg JI, Perry MD, Perrin MJ, Mann SA, Ke Y, Hill AP. hERG K $(+)$ channels: structure, function, and clinical significance. Physiol Rev. 2012; 92:1393-478.

16. Liu H, Yang L, Jin MW, Sun HY, Huang Y, Li GR. The selective estrogen receptor modulator raloxifene inhibits cardiac delayed rectifier potassium currents and voltagegated sodium current without QTc interval prolongation. Pharmacol Res. 2010; 62:384-90.

17. Drolet B, Simard C, Roden DM. Unusual effects of a QT-prolonging drug, arsenic trioxide, on cardiac potassium currents. Circulation. 2004; 109:26-29.

18. Adelsberger H, Quasthoff S, Grosskreutz J, Lepier A, Eckel F, Lersch C. The chemotherapeutic oxaliplatin alters voltage-gated $\mathrm{Na}(+)$ channel kinetics on rat sensory neurons. Eur J Pharmacol. 2000; 406:25-32.

19. Roden DM. Long QT syndrome: reduced repolarization reserve and the genetic link. J Intern Med. 2006; 259:59-69.

20. Moss AJ, Schwartz PJ, Crampton RS, Tzivoni D, Locati EH, MacCluer J, Hall WJ, Weitkamp L, Vincent GM, Garson A Jr, Jennifer L. The long QT syndrome. Prospective longitudinal study of 328 families. Circulation. 1991; 84:1136-44.

21. Garcia EV. T-wave alternans: reviewing the clinical performance, understanding limitations, characterizing methodologies. Ann Noninvasive Electrocardiol. 2008; 13:401-20.

22. Soignet SL, Frankel SR, Douer D, Tallman MS, Kantarjian H, Calleja E, Stone RM, Kalaycio M, Scheinberg DA, Steinherz P, Sievers EL, Coutré S, Dahlberg S, et al. United States multicenter study of arsenic trioxide in relapsed acute promyelocytic leukemia. J Clin Oncol. 2001; 19:3852-60.

23. Barbey JT, Pezzullo JC, Soignet SL. Effect of arsenic trioxide on QT interval in patients with advanced malignancies. J Clin Oncol. 2003; 21:3609-15.

24. Lu HR, Vlaminckx E, Cools F, Gallacher DJ. Direct effects of arsenic trioxide on action potentials in isolated cardiac tissues: importance of the choice of species, type of cardiac tissue and perfusion time. J Pharmacol Toxicol Methods. 2012; 66:135-44.

25. Chu W, Li C, Qu X, Zhao D, Wang X, Yu X, Cai F, Liang H, Zhang Y, Zhao X, Li B, Qiao G, Dong D, et al. Arsenicinduced interstitial myocardial fibrosis reveals a new insight into drug-induced long QT syndrome. Cardiovasc Res. 2012; 96:90-98.

26. Naito K, Kobayashi M, Sahara N, Shigeno K, Nakamura S, Shinjo K, Tobita T, Takeshita A, Ohno R, Ohnishi K. Two cases of acute promyelocytic leukemia complicated by torsade de pointes during arsenic trioxide therapy. Int $\mathrm{J}$ Hematol. 2006; 83:318-23.

27. Unnikrishnan D, Dutcher JP, Varshneya N, Lucariello R, Api M, Garl S, Wiernik PH, Chiaramida S. Torsades de pointes in 3 patients with leukemia treated with arsenic trioxide. Blood. 2001; 97:1514-16. 
28. Kumazaki M, Ando H, Kakei M, Ushijima K, Taniguchi Y, Yoshida M, Yamato S, Washino S, Koshimizu TA, Fujimura A. $\alpha$-Lipoic acid protects against arsenic trioxide-induced acute QT prolongation in anesthetized guinea pigs. Eur J Pharmacol. 2013; 705:1-10.

29. Simůnek T, Stérba M, Popelová O, Adamcová M, Hrdina R, Gersl V. Anthracycline-induced cardiotoxicity: overview of studies examining the roles of oxidative stress and free cellular iron. Pharmacol Rep. 2009; 61:154-71.

30. Sawyer DB, Peng X, Chen B, Pentassuglia L, Lim CC. Mechanisms of anthracycline cardiac injury: can we identify strategies for cardioprotection? Prog Cardiovasc Dis. 2010; 53:105-13.

31. Milberg P, Fleischer D, Stypmann J, Osada N, Mönnig G, Engelen MA, Bruch C, Breithardt G, Haverkamp W, Eckardt L. Reduced repolarization reserve due to anthracycline therapy facilitates torsade de pointes induced by IKr blockers. Basic Res Cardiol. 2007; 102:42-51.

32. Arbel Y, Swartzon M, Justo D. QT prolongation and Torsades de Pointes in patients previously treated with anthracyclines. Anticancer Drugs. 2007; 18:493-98.

33. Thomas D, Gut B, Karsai S, Wimmer AB, Wu K, WendtNordahl G, Zhang W, Kathöfer S, Schoels W, Katus HA, Kiehn J, Karle CA. Inhibition of cloned HERG potassium channels by the antiestrogen tamoxifen. Naunyn Schmiedebergs Arch Pharmacol. 2003; 368:41-48.

34. El Gebeily G, Fiset C. 4-Hydroxytamoxifen inhibits $\mathrm{K}(+)$ currents in mouse ventricular myocytes. Eur J Pharmacol. 2010; 629:96-103.

35. Asp ML, Martindale JJ, Metzger JM. Direct, differential effects of tamoxifen, 4-hydroxytamoxifen, and raloxifene on cardiac myocyte contractility and calcium handling. PLoS One. 2013; 8:e78768.

36. Woei Chung L, Liao YM, Hsieh CY, Lin CY. Oxaliplatininduced long QT syndrome in a patient with appendiceal adenocarcinoma. Acta Oncol. 2009; 48:156-57.

37. El-Awady ES, Moustafa YM, Abo-Elmatty DM, Radwan A. El-Awady el-SE1, Moustafa YM, Abo-Elmatty DM, Radwan A. Cisplatin-induced cardiotoxicity: mechanisms and cardioprotective strategies. Eur J Pharmacol. 2011; 650:335-41.

38. Chang RY, Lee MY, Kan CB, Hsu WP, Hsiao PC. Oxaliplatin-induced acquired long QT syndrome with torsades de pointes and myocardial injury in a patient with dilated cardiomyopathy and rectal cancer. J Chin Med Assoc. 2013; 76:466-69.

39. Kim HJ, An SH, Cho YH, Kim SY, Lee HG, Yoon SY. Oxaliplatin-induced Torsades de pointes and long QT syndrome in a patient with gastric cancer. Acta Oncol. 2013; 52:1223-24.

40. Oztop I, Gencer M, Okan T, Yaren A, Altekin E, Turker S, Yilmaz U. Evaluation of cardiotoxicity of a combined bolus plus infusional 5-fluorouracil/folinic acid treatment by echocardiography, plasma troponin I level, QT interval and dispersion in patients with gastrointestinal system cancers. Jpn J Clin Oncol. 2004; 34:262-68.

41. Chan CK, Chan MH, Tse ML, Chan IH, Cheung RC, Lam CW, Lau FL. Life-threatening Torsades de Pointes resulting from "natural" cancer treatment. Clin Toxicol (Phila). 2009; 47:592-94.

42. Sessions D, Heard K, Kosnett M. Fatal cesium chloride toxicity after alternative cancer treatment. J Altern Complement Med. 2013; 19:973-75.

43. Vyas H, Johnson K, Houlihan R, Bauer BA, Ackerman MJ. Acquired long QT syndrome secondary to cesium chloride supplement. J Altern Complement Med. 2006; 12:1011-14.

44. Saliba W, Erdogan O, Niebauer M. Polymorphic ventricular tachycardia in a woman taking cesium chloride. Pacing Clin Electrophysiol. 2001; 24:515-17.

45. Jones DL, Petrie JP, Li HG. Spontaneous, electrically, and cesium chloride induced arrhythmia and afterdepolarizations in the rapidly paced dog heart. Pacing Clin Electrophysiol. 2001; 24:474-85.

46. Tanriverdi O, Meydan N, Barutca S. Long-term effect of trastuzumab on QT dispersion in adjuvant treatment for patients with Her2 receptor positive breast cancer: a pilot study. Med Oncol. 2012; 29:3265-71.

47. Yavas O, Yazici M, Eren O, Oyan B. The acute effect of trastuzumab infusion on ECG parameters in metastatic breast cancer patients. Swiss Med Wkly. 2007; 137:556-58.

48. Oliva S, Cioffi G, Frattini S, Simoncini EL, Faggiano P, Boccardi L, Pulignano G, Fioretti AM, Giotta F, Lestuzzi C, Maurea N, Sabatini S, Tarantini L, and Italian CardioOncological Network. Administration of angiotensinconverting enzyme inhibitors and $\beta$-blockers during adjuvant trastuzumab chemotherapy for nonmetastatic breast cancer: marker of risk or cardioprotection in the real world? Oncologist. 2012; 17:917-24.

49. Shah MH, Binkley P, Chan K, Xiao J, Arbogast D, Collamore M, Farra Y, Young D, Grever M. Cardiotoxicity of histone deacetylase inhibitor depsipeptide in patients with metastatic neuroendocrine tumors. Clin Cancer Res. 2006; 12:3997-4003.

50. Lynch DR Jr, Washam JB, Newby LK. QT interval prolongation and torsades de pointes in a patient undergoing treatment with vorinostat: a case report and review of the literature. Cardiol J. 2012; 19:434-38.

51. Kim M, Thompson LA, Wenger SD, O'Bryant CL. Romidepsin: a histone deacetylase inhibitor for refractory cutaneous T-cell lymphoma. Ann Pharmacother. 2012; 46:1340-48.

52. Bruserud Ø, Stapnes C, Ersvaer E, Gjertsen BT, Ryningen A. Histone deacetylase inhibitors in cancer treatment: a review of the clinical toxicity and the modulation of gene expression in cancer cell. Curr Pharm Biotechnol. 2007; $8: 388-400$

53. Moslehi JJ. Cardiovascular toxic effects of targeted cancer therapies. N Engl J Med. 2016; 375:1457-67. 
54. Kim TD, le Coutre P, Schwarz M, Grille P, Levitin M, Fateh-Moghadam S, Giles FJ, Dörken B, Haverkamp W, Köhncke C. Clinical cardiac safety profile of nilotinib. Haematologica. 2012; 97:883-89.

55. Heigener DF, Reck M. Crizotinib. Recent Results Cancer Res. 2014; 201:197-205.

56. Annunziata CM, Walker AJ, Minasian L, Yu M, Kotz H, Wood BJ, Calvo K, Choyke P, Kimm D, Steinberg SM, Kohn EC. Vandetanib, designed to inhibit VEGFR2 and EGFR signaling, had no clinical activity as monotherapy for recurrent ovarian cancer and no detectable modulation of VEGFR2. Clin Cancer Res. 2010; 16:664-72.

57. Fox E, Aplenc R, Bagatell R, Chuk MK, Dombi E, Goodspeed W, Goodwin A, Kromplewski M, Jayaprakash N, Marotti M, Brown KH, Wenrich B, Adamson PC, et al. A phase 1 trial and pharmacokinetic study of cediranib, an orally bioavailable pan-vascular endothelial growth factor receptor inhibitor, in children and adolescents with refractory solid tumors. J Clin Oncol. 2010; 28:5174-81.

58. Sonnichsen D, Dorer DJ, Cortes J, Talpaz M, Deininger MW, Shah NP, Kantarjian HM, Bixby D, Mauro MJ, Flinn IW, Litwin J, Turner CD, Haluska FG. Analysis of the potential effect of ponatinib on the QTc interval in patients with refractory hematological malignancies. Cancer Chemother Pharmacol. 2013; 71:1599-607.

59. Deremer DL, Ustun C, Natarajan K. Nilotinib: a secondgeneration tyrosine kinase inhibitor for the treatment of chronic myelogenous leukemia. Clin Ther. 2008; 30:1956-75.

60. Bello CL, Mulay M, Huang X, Patyna S, Dinolfo M, Levine S, Van Vugt A, Toh M, Baum C, Rosen L. Electrocardiographic characterization of the QTc interval in patients with advanced solid tumors: pharmacokineticpharmacodynamic evaluation of sunitinib. Clin Cancer Res. 2009; 15:7045-52.

61. Kazandjian D, Blumenthal GM, Chen HY, He K, Patel M, Justice R, Keegan P, Pazdur R. FDA approval summary: crizotinib for the treatment of metastatic non-small cell lung cancer with anaplastic lymphoma kinase rearrangements. Oncologist. 2014; 19:e5-11.

62. Masters GA, Temin S, Azzoli CG, Giaccone G, Baker S Jr, Brahmer JR, Ellis PM, Gajra A, Rackear N, Schiller JH, Smith TJ, Strawn JR, Trent D, Johnson DH, and American Society of Clinical Oncology Clinical Practice. Systemic Therapy for Stage IV Non-Small-Cell Lung Cancer: American Society of Clinical Oncology Clinical Practice Guideline Update. J Clin Oncol. 2015; 33:3488-515.

63. Shah RR, Morganroth J, Shah DR. Cardiovascular safety of tyrosine kinase inhibitors: with a special focus on cardiac repolarisation (QT interval). Drug Saf. 2013; 36:295-316.

64. Le DL, Cao H, Yang LX. Cardiotoxicity of moleculartargeted drug therapy. Anticancer Res. 2014; 34:3243-49.

65. Dong Q, Fu XX, Du LL, Zhao N, Xia CK, Yu KW, Cheng LX, Du YM. Blocking of the human ether-à-go-go-related gene channel by imatinib mesylate. Biol Pharm Bull. 2013; $36: 268-75$.

66. Lee HA, Kim EJ, Hyun SA, Park SG, Kim KS. Electrophysiological effects of the anti-cancer drug lapatinib on cardiac repolarization. Basic Clin Pharmacol Toxicol. 2010; 107:614-18.

67. Poterucha JT, Westberg M, Nerheim P, Lovell JP. Rituximab-induced polymorphic ventricular tachycardia. Tex Heart Inst J. 2010; 37:218-20.

68. Cervera Grau JM, Esquerdo Galiana G, Belso Candela A, Llorca Ferrándiz C, Juárez Marroquí A, Maciá Escalante $\mathrm{S}$. Complete atrioventricular block induced by rituximab in monotherapy in an aged patient with non-Hodgkin's diffuse large B-cell lymphoma. Clin Transl Oncol. 2008; 10:298-99.

69. Armitage JD, Montero C, Benner A, Armitage JO, Bociek G. Acute coronary syndromes complicating the first infusion of rituximab. Clin Lymphoma Myeloma. 2008; 8:253-55.

70. Passalia C, Minetto P, Arboscello E, Balleari E, Bellodi A, Del Corso L, Molinari E, Ponassi I, Oneto C, Sicbaldi V, Ghio R. Cardiovascular adverse events complicating the administration of rituximab: report of two cases. Tumori. 2013; 99:288e-92e.

71. Ibrahim MA, Do DV, Sepah YJ, Shah SM, Van Anden E, Hafiz G, Donahue JK, Rivers R, Balkissoon J, Handa JT, Campochiaro PA, Nguyen QD. Vascular disrupting agent for neovascular age related macular degeneration: a pilot study of the safety and efficacy of intravenous combretastatin A-4 phosphate. BMC Pharmacol Toxicol. 2013; 14:7.

72. Cooney MM, Radivoyevitch T, Dowlati A, Overmoyer B, Levitan N, Robertson K, Levine SL, DeCaro K, Buchter C, Taylor A, Stambler BS, Remick SC. Cardiovascular safety profile of combretastatin a4 phosphate in a single-dose phase I study in patients with advanced cancer. Clin Cancer Res. 2004; 10:96-100.

73. Bhakta S, Flick SM, Cooney MM, Greskovich JF, Gilkeson RC, Remick SC, Ortiz J. Myocardial stunning following combined modality combretastatin-based chemotherapy: two case reports and review of the literature. Clin Cardiol. 2009; 32:E80-84.

74. Flaherty L, Hamid O, Linette G, Schuchter L, Hallmeyer S, Gonzalez R, Cowey CL, Pavlick A, Kudrik F, Curti B, Lawson D, Chapman PB, Margolin K, et al. A singlearm, open-label, expanded access study of vemurafenib in patients with metastatic melanoma in the United States. Cancer J. 2014; 20:18-24.

75. Jordan EJ, Kelly CM. Vemurafenib for the treatment of melanoma. Expert Opin Pharmacother. 2012; 13:2533-43.

76. Rademaker-Lakhai JM, Beerepoot LV, Mehra N, Radema SA, van Maanen R, Vermaat JS, Witteveen EO, VisserenGrul CM, Musib L, Enas N, van Hal G, Beijnen JH, Schellens JH, Voest EE. Phase I pharmacokinetic and pharmacodynamic study of the oral protein kinase $\mathrm{C}$ 
beta-inhibitor enzastaurin in combination with gemcitabine and cisplatin in patients with advanced cancer. Clin Cancer Res. 2007; 13:4474-81.

77. Topilski I, Rogowski O, Rosso R, Justo D, Copperman Y, Glikson M, Belhassen B, Hochenberg M, Viskin S. The morphology of the QT interval predicts torsade de pointes during acquired bradyarrhythmias. J Am Coll Cardiol. 2007; 49:320-28.

78. Panikkath R, Reinier K, Uy-Evanado A, Teodorescu C, Hattenhauer J, Mariani R, Gunson K, Jui J, Chugh SS. Prolonged Tpeak-to-tend interval on the resting ECG is associated with increased risk of sudden cardiac death. Circ Arrhythm Electrophysiol. 2011; 4:441-47.

79. Verrier RL, Klingenheben T, Malik M, El-Sherif N, Exner DV, Hohnloser SH, Ikeda T, Martínez JP, Narayan SM, Nieminen T, Rosenbaum DS. Microvolt T-wave alternans physiological basis, methods of measurement, and clinical utility - consensus guideline by International Society for Holter and Noninvasive Electrocardiology. J Am Coll Cardiol. 2011; 58:1309-24.

80. Lu HR, Yan GX, Gallacher DJ. A new biomarker-index of cardiac electrophysiological balance (iCEB) - plays an important role in drug-induced cardiac arrhythmias: beyond QT-prolongation and Torsades de Pointes (TdPs). J Pharmacol Toxicol Methods. 2013; 68:250-59.

81. Niemeijer MN, van den Berg ME, Eijgelsheim M, Rijnbeek PR, Stricker BH. Pharmacogenetics of Drug-Induced QT Interval Prolongation: an Update. Drug Saf. 2015; 38:855-67.

82. Lehtonen A, Fodstad H, Laitinen-Forsblom P, Toivonen L, Kontula K, Swan H. Further evidence of inherited long QT syndrome gene mutations in antiarrhythmic drug-associated torsades de pointes. Heart Rhythm. 2007; 4:603-07.

83. Eap CB, Crettol S, Rougier JS, Schläpfer J, Sintra Grilo L, Déglon JJ, Besson J, Croquette-Krokar M, Carrupt PA, Abriel H. Stereoselective block of hERG channel by (S)-methadone and QT interval prolongation in CYP2B6 slow metabolizers. Clin Pharmacol Ther. 2007; 81:719-28.

84. Abbas R, Hug BA, Leister C, Sonnichsen D. A randomized, crossover, placebo- and moxifloxacin-controlled study to evaluate the effects of bosutinib (SKI-606), a dual Src/ Abl tyrosine kinase inhibitor, on cardiac repolarization in healthy adult subjects. Int J Cancer. 2012; 131:E304-11.

85. Johnson FM, Agrawal S, Burris H, Rosen L, Dhillon N, Hong D, Blackwood-Chirchir A, Luo FR, Sy O, Kaul $\mathrm{S}$, Chiappori AA. Phase 1 pharmacokinetic and druginteraction study of dasatinib in patients with advanced solid tumors. Cancer. 2010; 116:1582-91.

86. Nishimoto $\mathrm{M}$, Nakamae $\mathrm{H}$, Matsumoto $\mathrm{K}$, Morita $\mathrm{K}$, Koga Y, Momose D, Hino M. Dasatinib and Prednisolone Induction Therapy for a Case of Philadelphia ChromosomePositive Acute Lymphoblastic Leukemia with Dilated Cardiomyopathy Accompanied by Life-Threatening
Ventricular Tachycardia. Case Rep Hematol. 2017; 2017:4027908.

87. Shumaker RC, Zhou M, Ren M, Fan J, Martinez G, Aluri J, Darpo B. Effect of lenvatinib (E7080) on the QTc interval: results from a thorough QT study in healthy volunteers. Cancer Chemother Pharmacol. 2014; 73:1109-17.

88. Shah RR, Morganroth J. Update on Cardiovascular Safety of Tyrosine Kinase Inhibitors: With a Special Focus on QT Interval, Left Ventricular Dysfunction and Overall Risk/ Benefit. Drug Saf. 2015; 38:693-710.

89. Goss G, Tsai CM, Shepherd FA, Bazhenova L, Lee JS, Chang GC, Crino L, Satouchi M, Chu Q, Hida T, Han JY, Juan O, Dunphy F, et al. Osimertinib for pretreated EGFR Thr790Met-positive advanced non-small-cell lung cancer (AURA2): a multicentre, open-label, single-arm, phase 2 study. Lancet Oncol. 2016; 17:1643-52.

90. Ghatalia P, Je Y, Kaymakcalan MD, Sonpavde G, Choueiri TK. QTc interval prolongation with vascular endothelial growth factor receptor tyrosine kinase inhibitors. Br J Cancer. 2015; 112:296-305.

91. Bronte E, Bronte G, Novo G, Bronte F, Bavetta MG, Lo Re G, Brancatelli G, Bazan V, Natoli C, Novo S, Russo A. What links BRAF to the heart function? New insights from the cardiotoxicity of BRAF inhibitors in cancer treatment. Oncotarget. 2015; 6:35589-601. https://doi.org/10.18632/ oncotarget.5853.

92. Lesimple T, Edeline J, Carrothers TJ, Cvitkovic F, Darpo B, Delord JP, Léna H, Penel N, Edwards GJ, Law K, Wanders J, Kristensen A, Reyderman L. A phase I, open-label, single-arm study for QT assessment of eribulin mesylate in patients with advanced solid tumors. Invest New Drugs. 2013; 31:900-09.

93. Walker AR, Klisovic R, Johnston JS, Jiang Y, Geyer S, Kefauver C, Binkley P, Byrd JC, Grever MR, Garzon R, Phelps MA, Marcucci G, Blum KA, Blum W. Pharmacokinetics and dose escalation of the heat shock protein inhibitor 17-allyamino-17-demethoxygeldanamycin in combination with bortezomib in relapsed or refractory acute myeloid leukemia. Leuk Lymphoma. 2013; 54:1996-2002.

94. Moudgil R, Yeh ET. Mechanisms of Cardiotoxicity of Cancer Chemotherapeutic Agents: cardiomyopathy and Beyond. Can J Cardiol. 2016; 32:863-870.e5.

95. Franco TH, Khan A, Joshi V, Thomas B. Takotsubo cardiomyopathy in two men receiving bevacizumab for metastatic cancer. Ther Clin Risk Manag. 2008; 4:1367-70.

96. Kosmas C, Kallistratos MS, Kopterides P, Syrios J, Skopelitis H, Mylonakis N, Karabelis A, Tsavaris N. Cardiotoxicity of fluoropyrimidines in different schedules of administration: a prospective study. J Cancer Res Clin Oncol. 2008; 134:75-82.

97. Ewer MS, Ewer SM. Cardiotoxicity of anticancer treatments: what the cardiologist needs to know. Nat Rev Cardiol. 2010; 7:564-75. 